$1-1-2007$

\title{
A New Twist to the Substitute-for-Ordinary Income Doctrine: Third Circuit Adopts "Family Resemblance" Test to Characterize Sale of Lottery Proceeds as Ordinary Income
}

Timothy R. Koski

\section{How does access to this work benefit you? Let us know!}

Follow this and additional works at: https://commons.und.edu/ndlr

Part of the Law Commons

\section{Recommended Citation}

Koski, Timothy R. (2007) "A New Twist to the Substitute-for-Ordinary Income Doctrine: Third Circuit Adopts "Family Resemblance" Test to Characterize Sale of Lottery Proceeds as Ordinary Income," North Dakota Law Review. Vol. 83: No. 1, Article 2.

Available at: https://commons.und.edu/ndlr/vol83/iss1/2

This Article is brought to you for free and open access by the School of Law at UND Scholarly Commons. It has been accepted for inclusion in North Dakota Law Review by an authorized editor of UND Scholarly Commons. For more information, please contact und.commons@library.und.edu. 


\title{
A NEW TWIST TO THE SUBSTITUTE-FOR-ORDINARY INCOME DOCTRINE: THIRD CIRCUIT ADOPTS “FAMILY RESEMBLANCE” TEST TO CHARACTERIZE SALE OF LOTTERY PROCEEDS AS ORDINARY INCOME
}

\author{
TIMOTHY R. KosKI
}

\section{INTRODUCTION}

In Lattera $v$. Commissioner, 1 the Third Circuit Court of Appeals recently held that the sale of the right to future lottery payments is ordinary income rather than capital gain. The Third Circuit agreed with the result reached by the Ninth Circuit Court of Appeals in United States $v$. Maginnis, ${ }^{2}$ and became the second federal appellate court to treat the sale of lottery proceeds as ordinary income. However, the Third Circuit did not adopt the Ninth Circuit's reasoning. Instead, in an opinion commentators have suggested is "[d] estined for law school casebooks," 3 the Third Circuit adopted a "family resemblance" test to guide their analysis in cases decided under the substitute-for-ordinary income doctrine. If adopted by other courts, the family resemblance test will significantly impact the substitutefor-ordinary income doctrine.

Part II of this article introduces the ordinary income versus capital gain issue and discusses the definition of capital asset. Part III reviews the substitute-for-ordinary income doctrine. Part IV discusses how the substitutefor-ordinary income doctrine applies to the sale of future lottery payments prior to Lattera. Part V examines the Third Circuit's decision in Lattera. Part VI analyzes the family resemblance test as applied to the substitutefor-ordinary income doctrine.

*J.D., 1985, University of North Dakota; LL.M. (Taxation), 1986, Southern Methodist University; Ph.D. in Accounting, 1998, University of Missouri-Columbia. Timothy R. Koski is a certified public accountant and attorney specializing in taxation. He is currently the Crowe Chizek Distinguished Professor of Accounting at Middle Tennessee State University.

1. 437 F.3d 399 (3d Cir. 2006).

2. 356 F.3d 1179 (9th Cir. 2004).

3. Susan Simmons, Third Circuit Adopts "Family" Approach to Asset Treatment, 110 TAX NOTES 953, 953 (2006). 


\section{CAPITAL VERSUS ORDINARY INCOME}

A net long-term capital gain is currently taxed at a maximum rate of fifteen percent. ${ }^{4}$ Given the current top marginal rate of thirty-five percent, 5 taxpayers have significant incentive to classify the sale of property as longterm capital gain rather than ordinary income. As discussed herein, however, taxpayers have been unsuccessful in their efforts to classify gain from the sale of future lottery payments as capital.

Internal Revenue Code section 1221(a) defines a capital asset as "[p]roperty held by the taxpayer (whether or not connected with his trade or business)...."6 As a result of this definition, all property is statutorily capital unless specifically excluded. Section 1221(a) goes on to provide several statutory exceptions to capital asset treatment. ${ }^{7}$ The sale of future lottery payments does not fall within one of these statutory exceptions.

Although the Code defines capital asset by exclusion, it is well established that not all assets qualify as capital even though they do not fall within any of the exceptions to capital asset treatment set forth in section 1221(a). ${ }^{8}$ In Commissioner v. Gillette Motor Transport, Inc., ${ }^{9}$ for example, the Supreme Court stated "[n]ot everything which can be called property in the ordinary sense and which is outside the statutory exclusions qualifies as a capital asset."10 The substitute-for-ordinary income doctrine has evolved to narrowly construe the definition of capital asset to prevent taxpayers

4. 26 U.S.C. $\S 1(\mathrm{~h})(1(\mathrm{C})$ (2006). The current maximum rate on a net long-term capital gain is five percent for taxpayers in the ten or fifteen percent tax bracket. Id. In order to qualify as a long-term capital gain there must be a sale or exchange of a capital asset held more than twelve months. Id. $\S 1222(3)$. The sale or exchange requirement is beyond the scope of this article.

5. See generally 26 U.S.C. § 1(i)(2) (2006).

6. Id. $\S 1221$ (a).

7. Id. Property excluded from capital asset treatment under section 1221(a) includes stock in trade of the taxpayer or other property which would normally be included in inventory or held primarily for sale to customers in the ordinary course of business $(\$ 1221(\mathrm{a})(1))$, real or depreciable property used in a trade or business $(\$ 1221(\mathrm{a})(2))$, "a copyright, a literary, musical or artistic composition, a letter or memoranda or similar property" held by a taxpayer whose personal efforts created such property or whose basis is determined by reference to the basis of the taxpayer whose personal efforts created such property $(\S 1221(a)(3))$, "accounts or notes receivable acquired in the ordinary course of trade or business for services rendered or from the sale of inventory" ( $\$ 1221(\mathrm{a})(4))$, a U.S. government publication held by a taxpayer who receives the publication by means other than purchase at the price the publication is offered for sale to the public $(\$ 1221(\mathrm{a})(5))$, "a commodities derivative financial instrument held by a commodities derivatives dealer" unless it is established that the instrument has no connection with activities as a dealer and it is clearly identified as such $(\$ 1221(a)(6))$, "any hedging transaction which is clearly identified as such" (\$1221(a)(7)), and supplies regularly used or consumed as supplies in the normal course of business (\$1221(a)(8)). Id. § 1221(a)(1)-(8).

8. See, e.g., Maginnis, 356 F.3d 1179, 1187 (9th Cir. 2004) (holding lottery rights are not taxed as ordinary income).

9. 364 U.S. 130 (1960).

10. Gillette Motor, 364 U.S. at 134. 
from artificially converting what otherwise would be ordinary income into capital gain in situations where treating the property as capital would undermine the reason for treating capital assets differently. 11

\section{THE SUBSTITUTE-FOR-ORDINARY INCOME DOCTRINE}

\section{A. DEVELOPMENT OF THE SUBSTITUTE-FOR-ORDINARY INCOME DOCTRINE}

The substitute-for-ordinary income doctrine holds that lump sum consideration substituting for something that would be treated as ordinary income in the future should be treated as ordinary rather than capital. 12 The beginning of the doctrine can be traced to the Supreme Court's decision in Hort v. Commissioner. 13 The taxpayer in Hort inherited a ten-story office building from his father. ${ }^{14}$ At the time of the inheritance, the building was leased to a firm, which had sublet the main floor to a bank. 15 Five years before the head lease expired, the taxpayer's father and the bank entered into an agreement whereby the bank was to lease the main floor and basement for a term of fifteen years for annual payments of $\$ 25,000$ per year, the term to commence at the expiration of the head lease. 16 Because of changing economic conditions brought on by the Depression, the bank found it unprofitable to maintain an office in the building and sought to cancel the lease before its expiration. 17 The taxpayer agreed to cancel the lease in return for a $\$ 140,000$ lease cancellation payment. 18 The taxpayer reported an ordinary loss equal to the difference between the present value of the future rental payments and the fair rental value of the main floor and basement for the remaining term of the lease. 19 The Internal Revenue Service (IRS) disallowed the entire loss and included the $\$ 140,000$ cancellation payment in the taxpayer's income. ${ }^{20}$

11. Id.

12. Lattera v. Comm'r, 437 F.3d 399, 403 (3d Cir. 2006) (citation omitted).

13. 313 U.S. 28 (1941).

14. Hort, 313 U.S. at 29.

15. Id.

16. Id. This agreement was executed in 1927 , one year before the taxpayer inherited the building. $I d$.

17. Id.

18. Id.

19. Id. The taxpayer reported a loss of $\$ 21,494.75$. However, the taxpayer did not deduct the loss because he reported other losses in excess of his gross income. Id.

20. Id. 
The Supreme Court held that the cancellation payment received by the taxpayer was ordinary income in its entirety.21 Canceling the lease "involved nothing more than relinquishment of the right to future rental payments in return for a present substitute payment and possession of the leased premises." 22 The Supreme Court assumed that the lease was property.23 The fact that the lease was property, however, does not necessarily mean the amount received for its cancellation was a return of capital.24 The Supreme Court noted that the bond in Helvering v. Horst 25 and the building in Helvering $v$. Bruun 26 were presumably property, but the interest coupon in Horst and the building in Bruun were nevertheless held to be income. 27 The disputed amount was "essentially a substitute for rental payments," which is properly characterized as ordinary income. ${ }^{28}$ The Supreme Court also disallowed the claimed loss on the lease cancellation. ${ }^{29}$ Although the taxpayer may have been economically injured by the lease cancellation, a deductible loss arises "only when its extent had been fixed by a closed transaction." 30

The substitute-for-ordinary income doctrine became more fully developed in Commissioner v. P.G. Lake, Inc. ${ }^{31}$ The taxpayer in Lake was a corporation engaged in the oil and gas business. ${ }^{32}$ It assigned an oil payment right of twenty-five percent of oil attributable to its working interest in two leases to its president in return for cancellation of a $\$ 600,000$

21. Id. at 30. Interestingly, certiorari was granted in Hort limited to the question of whether "in computing net gain or loss for income tax purposes, a taxpayer [can] offset the value of the lease canceled against the consideration received by him for the cancellation." Id. (citation omitted). The Supreme Court's opinion, however, was mainly concerned with ordinary income versus capital gain classification.

22. Id. at 32. Section $1234 \mathrm{~A}$ was added to the Internal Revenue Code by the Tax Reform Act of 1997 effectively overruling Hort as it applies to lease cancellation payments by providing that any gain attributable to the cancellation or other termination of a right with respect to property which is a capital asset in the hands of the taxpayer is capital gain. See generally Edward J. Roche Jr., Lease Cancellation Payments are Capital Gain? Yes!' The TRA '97 Change to 1234A Overturned Hort, 102 J. TAX'N 364 (2005). This legislative change in no way undermines the general authority of Hort as it applies to the substitute-for-ordinary income doctrine.

23. Hort, 313 U.S. at 31.

24. Id.

25. 311 U.S. 112 (1940) (finding income from detachable interest coupons taxed to the owner of the bonds).

26. 309 U.S. 461 (1940) (finding the value of leasehold improvements made by tenant included in landlord's income upon forfeiture of lease for nonpayment of rent). The result in Bruun was effectively overruled by the enactment of section 109 of the Internal Revenue Code.

27. Hort, 313 U.S. at 31.

28. Id.

29. Id. at 32 .

30. Id. at 33. Presumably, a closed transaction would be the sale of the underlying building.

31. 356 U.S. 260 (1958) (consolidating five cases with an identical question of law).

32. P.G. Lake, Inc., 356 U.S. at 261. 
debt, and reported the assignment as the sale of a capital asset.33 The Supreme Court held that the payment received for the assignment was ordinary income. 34 The consideration received was "essentially a substitute for what would otherwise be received at a future time as ordinary income." 35 The Supreme Court saw no conversion of a capital investment. 36 The amount to be received from the working interests could be ascertained with considerable accuracy and was paid for the right to receive future income, not for an increase in the value of the income-producing property. 37 The Supreme Court stated that arrangements such as that in Lake "seem to us transparent devices." 38 Their forms do not control the tax consequences. 39 Instead, "their essence is determined not by subtleties of draftsmanship but by their total effect." 40

In Gillette Motor the Supreme Court held that a sum received as compensation for the temporary taking of the taxpayer's business facilities during World War II was ordinary rather than capital.41 The taxpayer in Gillette Motor was a common carrier. ${ }^{42}$ In 1944, its drivers went on strike and the taxpayer completely ceased operations. ${ }^{43}$ Shortly thereafter, because of the need for the taxpayer's facilities in the transportation of war material, the government took possession and control of its operations. 44 Subject to orders given by the government from time to time, the taxpayer resumed normal operations and continued to function until government control of its operations ended. 45 The taxpayer presented a claim for just compensation to the Motor Claims Commission (Commission).46 The government argued that there had been no "taking" of the taxpayer's

33. Id. at 262 .

34. Id. at 264. Interestingly, the Supreme Court did not cite its previous decision in Hort, although the same basic principle was involved.

35. Id. at 265 .

36. Id.

37. Id. at 265-66.

38. Id. at 266.

39. Id.

40. Id. at 266-67. The Supreme Court also held that the transfer of the right to the oil payments did not qualify as a like-kind exchange because the transferred "oil payments" represent future income from oil payments and are of a different class of property than the realty transferred. Id. at 268.

41. Comm'r v. Gillete Motor Transp., Inc., 364 U.S. 130, 131 (1960).

42. Id. at 131 .

43. Id

44. Id.

45. Id. The taxpayer's operations were under government control from August 12, 1944, until June 16, 1945. Id.

46. Id. The Motor Carrier Claims Commission was created by an Act of Congress (62 Stat. 1222). Id. 
property, only a "regulation" of it. 47 The Commission determined that by assuming actual possession and control of the taxpayer's facilities, the government had deprived the taxpayer of the valued right to freely determine what use to be made of them. 48 The Commission further determined that the rental value of the facilities was a fair measure of the taxpayer's loss, and based the taxpayer's award on the fair rental value of its facilities during the time of government control.49 The IRS determined that the compensation award was ordinary income, while the taxpayer argued that it was an amount received upon the involuntary conversion of property and therefore capital. 50

The Supreme Court stated that although the taxpayer's right to use its transportation facilities was a valuable property right compensable under the Fifth Amendment, it was not a capital asset.51 "Not everything which can be called property in the ordinary sense and which is outside the statutory exclusion qualifies as a capital asset." 52 In an often quoted passage, the Supreme Court stated that they have long held that the term capital asset

[I]s to be construed narrowly in accordance with the purpose of Congress to afford capital-gains treatment only in situations typically involving the realization of appreciation in value accrued over a substantial period of time, and thus to ameliorate the hardship of taxation of the entire gain in one year. 53

The Supreme Court recognized that if the government had taken a fee for the taxpayer's facilities, or damaged them physically beyond ordinary wear and tear, the compensation would have been treated as gain from the involuntary conversion of capital assets. 54 The government, however, took only the right to determine how the facilities were to be used, not the facilities themselves.55 The taxpayer had no investment in that right separate and apart from the assets themselves. 56

The other Supreme Court decision often cited in connection with the substitute-for-ordinary income doctrine is United States v. Midland-Ross

47. Id.

48. Id.

49. Id. The taxpayer was awarded $\$ 122,926.21$, representing the fair rental value of its facilities during the period of government control, plus $\$ 34,917.78$ of interest. Id. at 132 .

50. Id. at 132 .

51. Id. at 135 .

52. Id. at 134.

53. Id. (citing Burnet v. Harmel, 287 U.S. 103, 106 (1932)).

54. Id. at 135 .

55. $I d$.

56. $I d$. 
Corporation. 57 The taxpayer in Midland-Ross "bought non-interest bearing promissory notes at prices discounted" below their face value. 58 The notes were sold for less than face value but more than the issue price. 59 The taxpayer reported the gains as capital, but the IRS determined that the original issue discount was interest taxable as ordinary income.60 The Supreme Court agreed.61 Justice Brennan cited Gillette Motor for the proposition that not all property that falls outside the statutory exclusion qualifies for capital asset status, and quoted it at length for the proposition that the term capital asset must be narrowly construed in accordance with congressional intent to limit capital treatment to situations involving the realization of appreciation over a substantial period of time being recognized in one year.62 Earned original discount serves the same function as stated interest and, like interest, should be taxed as ordinary income. 63

\section{B. CORN PRODUCTS AND ARKANSAS BEST}

Two other well-known Supreme Court cases are relevant to any review involving the definition of a capital asset-Corn Products Refining Company v. Commissioner, 64 and Arkansas Best Corporation $v$. Commissioner. 65 The taxpayer in Corn Products manufactured products made from grain corn.66 In order to insure an adequate supply of raw materials needed to make its product, the taxpayer purchased futures contracts for corn. 67 The futures contracts entitled the taxpayer to purchase a fixed amount of corn at a future date at a fixed price. 68 Delivery of corn was accepted when needed for operations, and unneeded contracts were sold.69 The taxpayer contended that gains and losses on the sale of these

57. 381 U.S. 54 (1965).

58. Midland-Ross, 381 U.S. at 55.

59. Id.

60. Id. at 56 .

61. Id.

62. Id. at 56-57.

63. Id. at 57.

64. 350 U.S. 46 (1955).

65. 485 U.S. 212 (1988). As discussed later, taxpayers have unsuccessfully argued that Arkansas Best effectively repealed the substitute-for-ordinary income doctrine. See infra notes 109-14 and accompanying text.

66. Corn Products, 350 U.S. at 48. The taxpayer manufactured corn starch, syrup, sugar and related products. $I d$.

67. Id. The taxpayer initiated the futures buying program after droughts in the corn belt caused a sharp increase in the price of spot corn. Id. Because of limited storage, the taxpayer found itself unable to buy corn at a price that would allow it to be competitive. Id.

68. Id.

69. Id. at $48-49$. 
futures contracts were capital.70 In the taxpayer's view capital asset status was appropriate because futures contracts are customarily viewed as security investments. ${ }^{71}$ The Supreme Court disagreed and held that the sale of futures contracts related to the purchase of raw materials resulted in ordinary income. 72

The purchase and sale of the futures contracts were an integral part of acquiring and protecting the company's operations. 73 Although the corn futures did not fall within one of the statutory exclusions to capital asset treatment, the Supreme Court stated that Congress intended that profits and losses from everyday business operations be treated as ordinary, rather than capital. 74 The preferential treatment provided to capital assets was intended only for transactions in property not in the normal course of business. 75 The Supreme Court noted that the IRS and courts have consistently distinguished speculative transition "in commodity futures from hedging transactions."76 Hedging transactions are viewed as insurance rather than dealing in capital assets and therefore ordinary gain or loss treatment is appropriate. 77

The scope of the Corn Products doctrine was narrowed in Arkansas Best. ${ }^{78}$ The taxpayer in Arkansas Best was a bank holding company that acquired approximately sixty-five percent of the stock of the National Bank of Commerce (National) in Dallas, Texas in 1968.79 "Between 1969 and 1974 [the taxpayer] more than tripled the number of shares it owned in [National], although its percentage interest remained relatively stable." 80 The acquisitions were prompted principally by National's need for capital. 81 As a result of the decline in the Dallas real estate industry, National was classified as a problem bank in 1972.82 The taxpayer sold the

70. Id. at 49 .

71. Id.

72. Id. at 50 .

73. Id. at 51 .

74. Id. at 51-52.

75. Id. at 52 .

76. Id. See generally I.R.S. GEN. Couns. MEM. 17322, XV-2, C.B. 151 (1936) (restated in part and superseded by Rev. Rul. 72-179, 1972-1 C.B. 57); Stewart Silk Corp. v. Comm'r, 9 T.C. 174 (1947); Estate of Battelle v. Comm'r, 47 B.T.A. 117 (1942); Grote v. Comm'r, 41 B.T.A. 247 (1940).

77. Corn Products, 350 U.S. at 52-53.

78. Arkansas Best Corp. v. Comm'r, 485 U.S. 212, 212 (1985).

79. Id. at 213-14.

80. Id. at 214 .

81. Id.

82. Id. 
bulk of the stock it owned in National in 1975.83 The taxpayer argued that the stock was purchased to protect its business reputation and claimed an ordinary loss deduction of $\$ 9,995,688.84$ Relying on Corn Products, the Tax Court held that the loss on stock purchased through 1972 was capital because the acquisitions were motivated primarily by investment, but that, with minor exceptions, the stock purchased after 1972 was purchased for a business purpose (to protect the taxpayer's reputation) and the loss realized from its sale was ordinary. 85 The Eighth Circuit Court of Appeals reversed the Tax Court's determination that the loss on the stock purchased after 1972 was ordinary. 86 The Eighth Circuit stated that the stock clearly fell within the section 1221 definition of capital asset and that the taxpayer's motive for acquiring the stock was irrelevant. 87

The Supreme Court agreed with the Eighth Circuit and held that the taxpayer's motive for acquiring an asset is irrelevant to whether the asset falls within section 1221's general definition of capital asset. 88 The taxpayer's loss was treated as capital because the stock is within section 1221 's broad definition of capital asset and is not in any of the categories of assets that are excluded. 89

Arkansas Best significantly narrowed the scope of the Corn Products doctrine. 90 The Supreme Court concluded that Corn Products "is properly interpreted as standing for the narrow proposition that hedging transactions that are an integral part of a business' inventory purchase system fall within the inventory exclusion of $\S 1221$."91 Because the taxpayer in Arkansas Best was not a dealer in securities, its purchase of National stock does not fall within the inventory exclusion to capital asset status and Corn Products does not apply. .92

83. Id.

84. Id.

85. Id. (citing 83 T.C. $640,653-654$ (1984)).

86. Arkansas Best Corp. v. Comm'r, 800 F.2d 215 (8th Cir. 1986).

87. Id. at 218 .

88. Arkansas Best, 485 U.S. at 223.

89. Id.

90. See generally Maria E. O'Neil, Arkansas Best Corporation v. Commissioner-The Demise of the Corn Products Doctrine?, 35 WAYNE L. REV. 1481 (1989) (providing a detailed review of Arkansas Best and its impact on the Corn Products doctrine).

91. Arkansas Best, 485 U.S. at 222.

92. Id. 


\section{Limits ON AND PROBLEMS INHERENT IN THE SUBSTITUTE-FOR- ORDINARY INCOME DOCTRINE}

The substitute-for-ordinary income doctrine is well established. It has been used to prevent taxpayers from converting ordinary income into capital gain in a variety of different circumstances. Courts, however, have struggled to consistently apply the doctrine. 93 As noted by the Ninth Circuit in Maginnis "unless and until Congress establishes an arbitrary line on the otherwise seamless spectrum between [substitute-for-ordinary income] transactions and conventional capital gain transactions, the courts must locate the boundary case-by-case, a process that can yield few generalizations because there are so many relevant but imponderable criteria." 94

The substitute-for-ordinary income doctrine is difficult to apply because it is overly broad.95 This doctrine's breadth can be traced back to Hort and Lake. The Supreme Court could have decided Hort without using the broad substitute-for-ordinary income language. 96 They could have simply held that a right to future income carved out of a larger estate does not qualify as a capital asset and does not absorb any of the taxpayer's basis in the property. Commentators, in fact, have viewed the substitute-forordinary income language as a shorthand way of asserting this fact. 97

As a result of the substitute-for-ordinary income doctrine's breadth, courts and commentators have struggled to place appropriate limits on it. Commentators have suggested that theoretically every capital asset is a substitute-for-ordinary income. 98 Common stock, for example, can be seen as the present value of a future income stream. 99 Taking the substitute-forordinary income doctrine this far would cause the sale of all income producing assets to be taxed as ordinary income. 100 The struggle to find appropriate limits for the substitute-for-ordinary income doctrine is ongoing, and will be discussed further as the way courts have applied the doctrine to the sale of future lottery payments will be reviewed.

93. See generally United States v. Maginnis, 356 F.3d 1179 (9th Cir. 2004).

94. Id. at 1182 (quoting BORIS I. BITTKER \& LAWRENCE LOKKEN, FEDERAL TAXATION OF INCOME, ESTATES AND GIFT 47.1 (3d ed. 2000)).

95. See generally David F. Shores, Reexamining the Relationship Between Capital Gain and the Assignment of Income, 13 IND. L. REV. 463 (1980); MARVIN A. CHIRELSTEIN, FEDERAL INCOME TAXATION 383 (10th ed. 2005).

96. CHIRELSTEIN, supra note 95, at 384.

97. Id. This is similar to the vertical carve-out factor adopted by the Third Circuit in Lattera.

98. Id. See also Shores, supra note 95, at 501.

99. CHIRELSTEIN, supra note 95, at 381.

100. $I d$. 


\section{THE SALE OF FUTURE LOTTERY PAYMENTS PRIOR TO LATTERA}

\section{A. TAX COURT}

The Tax Court first addressed the issue of the character of proceeds received from the sale of future lottery payments in James E Davis, et ux $v$. Commissioner. 101 The taxpayers in Davis won $\$ 13,580,000$ in the California state lottery in 1991.102 The taxpayers were entitled to twenty equal annual payments of $\$ 679,000.103$ After receiving six annual payments, the taxpayers assigned a portion of each of the next eleven payments to a finance company for $\$ 1,040,000.104$ Under the terms of the assignment, the finance company was to receive $\$ 165,000$ of each of the taxpayer's next eleven payments, with the taxpayers receiving the remaining $\$ 514,000.105$ The taxpayers reported the $\$ 514,000$ as ordinary income, and the $\$ 1,040,000$ received from the assignment as proceeds received from the sale of a capital asset.106 The IRS determined that the $\$ 1,040,000$ received from the partial assignment of the future lottery payments was ordinary income. 107

The Tax Court held that the finance company paid the taxpayers for the right to receive future ordinary income, not for an increase in the value of income-producing property. 108 They further held that the right to receive future annual lottery payments did not constitute a capital asset within the meaning of section 1221, and that the $\$ 1,040,000$ received from the assignment was ordinary income rather than capital gain. 109

101. 119 T.C. 1 (1997).

102. Id. at 2. Mr. Davis won the lottery and later assigned his right to receive the annual payments to himself and his spouse as co-trustees of the James and Dorothy Davis Family Trust. $I d$. at $2 \mathrm{n} .2$. Mr. Davis treated the lottery payments as includable in his income. Id.

103. Id. at 2. At the time, California lottery winners did not have the option to receive a lump sum payment. Id.

104. Id. at 3. California law precluded a lottery winner from assigning the right to receive future lottery payments without obtaining California Superior Court approval. Id. Mr. Davis obtained court approval to assign the future lottery payments on August 1, 1977. Id.

105. $I d$. at 3 .

106. Id. at 4 . The taxpayers originally reported a cost basis of $\$ 7009$, consisting of the legal fees incurred in connection with the assignment. Id. at 1-2 n.1. The Service disallowed this cost basis and determined it to be a miscellaneous itemized deduction. Id. The taxpayers did not address the cost basis issue on appeal and the Tax Court concluded they had abandoned that position. $I d$.

107. Id. at 4 .

108. Id. at 7 .

109. Id. 
The Tax Court stated that it reviewed Hort, Lake, Gillette Motor, Midland-Ross, and their progeny in making its determination.110 Interestingly, the Tax Court noted that the taxpayers in Davis conceded that before the Supreme Court's decision in Arkansas Best, Hort and its progeny would have precluded characterizing the right to receive future lottery payments as capital.111 Instead, they argued that Arkansas Best effectively overruled the cases that established the substitute-for-ordinary income doctrine.112 The Tax Court disagreed.113 They based their conclusion on footnote five of Arkansas Best, in which the Supreme Court stated that the petitioner mistakenly relied on Hort and the substitute-for-ordinary income line of cases in support of its argument that the loss on the bank stock was ordinary.114 According to footnote five, "[t]his line of cases, based on the premise that $\S 1221$ 'property' does not include claims or rights to ordinary income, has no application in the present context. Petitioner sold capital stock, not a claim to ordinary income." 115

The Tax Court has addressed the issue of whether the sale of lottery payments is ordinary income or capital gain in several subsequent memorandum opinions. ${ }^{116}$ In each case they followed their analysis in Davis and reaffirmed their position without extensive analysis. 117

\section{B. THE NinTH CIRCUIT's DECISION IN MAGINNIS}

\section{Facts}

The taxpayers in Maginnis won $\$ 9,000,000$ in the Oregon state lottery in July 1999.118 The prize was payable in twenty equal annual installments of $\$ 450,000$ via an annuity policy purchased by the state of Oregon.119

110. Id.

111. Id.

112. $I d$.

113. Id. The Tax Court noted that they had previously concluded that Arkansas Best in no way affected the viability of the substitute-for-ordinary income doctrine established by Hort and its progeny. Id. See Gladden v. Comm'r, 112 T.C. 209, 221 (1999), rev'd on other grounds, 262 F.3d 851 (9th Cir. 2001).

114. Id. at 6-7.

115. Id. at 7 (quoting Arkansas Best Corp v. Comm'r, 485 U.S. 212, 217 n.5 (1988)).

116. See generally Simpson v. Comm'r, 85 T.C.M. (CCH) 1421 (2003); Johns v. Comm'r, 85 T.C.M. (CCH) 1318 (2003); Boehme v. Comm'r, 85 T.C.M. (CCH) 1039 (2003); Clopton v. Comm'r, 87 T.C.M. (CCH) 1217 (2004); Watkins v. Comm'r, T.C.M. (RIA) 2004-244.

117. See Simpson, 85 T.C.M. (CCH) at 1423 ; Johns, 85 T.C.M. $(\mathrm{CCH})$ at 1319 ; Boehme, 85 T.C.M. (CCH) at 1041; Clopton, 87 T.C.M. (CCH) at 1219; Watkins, 88 T.C.M. (RIA) at 247.

118. United States v. Maginnis, 356 F.3d 1179, 1180 (9th Cir. 2004). The total lottery prize of $\$ 23$ million was shared by the taxpayers and their three sons. Only the tax treatment of the taxpayer's sale of their $\$ 9$ million share of the total prize was at issue in Maginnis. Id.

119. Id. 
After receiving fifteen installments, the taxpayers assigned their right to the remaining fifteen installments to a finance company in return for $\$ 3,950,000.120$ The taxpayer initially reported the entire $\$ 3,950,000$ received as ordinary income and paid the full amount of tax due on their 1996 return. 121 In 1998, the taxpayers filed an amended return claiming the sale of the future lottery payments was capital gain rather than ordinary income. 122 The IRS initially granted the taxpayer's refund claim. ${ }^{123}$ They later determined that the lottery proceeds received were ordinary income, and brought suit to recover the amount erroneously refunded to the taxpayers. 124

An Oregon district court held that receipt of the lottery payments was ordinary income, and granted the IRS's motion for summary judgment. 125 The district court felt that capital asset treatment was not appropriate because "no asset appreciated." 126

\section{The Ninth Circuit Opinion}

The Ninth Circuit relied on the substitute-for-ordinary income doctrine to conclude that the taxpayers' assignment of future lottery payments was ordinary income. 127 The court recognized that the definition of capital asset has never been read as broadly as section 1221(a) seems to permit. 128 If the statutory definition of capital asset was read too broadly, "taxpayers might use simple accounting devices to convert all ordinary income into capital gains." 129 A right to be paid for work performed in the future, for example, does not fall within any of section 1221(a)'s statutory exceptions, but it is clear that Congress did not intend to treat future employment income as capital.130 The Ninth Circuit discussed how the substitute-for-ordinary income doctrine has been developed to narrowly construe the capital asset

120. Id. at 1181 . Oregon law did not allow the assignment of future lottery payments when the taxpayers won the lottery in 1991. Id. at 1180. Oregon amended their lottery statute in 1995 to allow lottery winners to petition a state court for permission to assign future lottery payments. Id. See OR. REV. STAT $\S \S 461.250(7)(\mathrm{a})(\mathrm{B}), 461.253$ (2003). Taxpayers successfully petitioned an Oregon state court to approve the assignment of their right to the remaining lottery payments in 1996. Maginnis, 356 F.3d at 1181.

121. Id.

122. Id.

123. Id. The taxpayers received a refund of $\$ 305,043$, plus interest. $I d$.

124. Id.

125. United States v. Maginnis, 89 A.F.T.R.2d (RIA) 3028, 3030 (2002).

126. Id.

127. Maginnis, 356 F.3d at 1187.

128. Id. at 1181 .

129. Id. at 1182 .

130. Id. at 1181-82 (citing BITTKER \& LOKKEN, supra note 94, J 47.1). 
definition to prevent artificial attempts to convert ordinary income into capital gain. 131

The Ninth Circuit also recognized limits on the substitute-for-ordinary income doctrine. 132 If the doctrine were taken too far, no sale of an asset that produces revenue would be capital. 133 Common stock, for example, is typically valued based on the present value of its future income stream.134 The Ninth Circuit made it clear that "case-by-case judgments" are needed to determine whether the conversion of income rights into lump sum payments is to be treated as ordinary or capital.135 They also recognized that this case-by-case analysis is "a process that can yield few generalizations because there are so many relevant but imponderable criteria." 136

The Ninth Circuit cited two factors as crucial to their conclusion. 137 The first crucial factor was that the taxpayers did not make any underlying investment of capital in return for receipt of the right to future lottery payments. 138 Lottery prizes are treated as gambling winnings, which are taxed as ordinary income. 139 According to the Ninth Circuit, the purchase of a lottery ticket is not a capital investment warranting capital asset treatment. ${ }^{140}$ The purchase of a lottery ticket "is no more an underlying investment of capital than is a dollar bet on the spin of a roulette wheel." 141

Selling the right to receive future lottery payments did not create a capital investment.142 The taxpayers could not have sold their right to future payments without first winning the lottery. ${ }^{143}$ Because they had no right to the future lottery payments until they won the lottery, and had made no capital investment before winning the lottery, no investment of capital was involved.144 Their assignment of the winnings was an assignment of gambling winnings, not an assignment of a capital asset. 145

The second factor crucial to the Ninth Circuit's decision was that the sale of the right to the lottery proceeds did not reflect an accretion in value

131. Id. at 1182 .

132. Id.

133. Id.

134. $I d$.

135. Id.

136. Id. (quoting BITTKER \& LOKKEN, supra note 94, I 47.9.5).

137. $I d$.

138. $I d$.

139. See 26 U.S.C. $§ 165(d)$; Comm'r v. Groetzinger, 480 U.S. 23, 35-36 (1987).

140. Maginnis, 356 F.3d at 1183 .

141. Id. at 1184 .

142. Id.

143. Id.

144. Id.

145. Id. 
over the cost of an underlying asset. 146 Because the taxpayers did not make any capital investment in exchange for the lottery right, there was no cost and the sale of the right "cannot plausibly be seen as reflecting an increase of value above the cost of any underlying capital asset." 147 Thus, the sale of the lottery proceeds "lacks the requisite "realization of appreciation in value accrued over a substantial period of time' that is typically necessary for capital gains treatment." 148

The Ninth Circuit stated that the sale of the right to future lottery proceeds is "almost indistinguishable from the paradigmatic situation in which the substitute for ordinary income doctrine removes a right to future income from the definition of a capital asset, which occurs when a taxpayer assigns his right to future income from employment to a third party for a lump sum."149 The Ninth Circuit also noted that treating the sale of future lottery proceeds as capital would reward lottery winners who elect to receive periodic payments and later sell the payment right. 150 A lump-sum lottery payment is taxed as ordinary income. 151 Allowing lottery winners who elect to receive their prize in installments to convert ordinary income into capital gain by selling their right to future payments would give them a tax advantage as compared to recipients of lump sum payments. ${ }^{152}$

The taxpayer in Maginnis also argued that Arkansas Best largely invalidated the substitute-for-ordinary income doctrine by limiting its application to two circumstances: a carve-out transaction in which the taxpayer retains some underlying interest in the property sold, and the right to future income from personal services. ${ }^{153}$ The Ninth Circuit dismissed this argument, stating that Arkansas Best did not affect the way in which the substitute-forordinary income doctrine modifies the term capital asset. 154 Arkansas Best dealt with an entirely different subject matter-whether motive was relevant for determining capital asset status. 155

The Ninth Circuit went on to address the taxpayer's carve-out argument. The court noted that the taxpayer was correct in his assertion that transactions in which a taxpayer transfers an income right without transferring his entire interest in the underlying asset are often occasions for

146. $I d$.

147. $I d$.

148. Id. (quoting Comm'r v. Gillette Motors Transp., Inc., 364 U.S. 130, 134 (1960)).

149. Id.

150. Id.

151. Id.

152. Id.

153. Id. at 1185 .

154. Id.

155. Id. 
applying the substitute-for-ordinary income doctrine.156 Allowing capital gain treatment where a taxpayer sells an income right and retains an interest in the underlying asset could encourage "all taxpayers owning stock or income-producing property ... to convert their ordinary investment income into capital gain." 157 However, this does not mean that the substitute-forordinary income doctrine only applies where a taxpayer retains an interest in the underlying property. 158 The Ninth Circuit stated that such an approach is foreclosed because they have previously applied the substitutefor-ordinary income doctrine to situations where a taxpayer disposes of his entire interest in the underlying property. 159

The Ninth Circuit also rejected the taxpayer's argument that capital gains treatment was appropriate because the lottery right was a debt instrument under section 1275.160 The taxpayer received the lottery payments as a prize, not as compensation for the use or forbearance of money. 161

\section{Criticism of Maginnis}

The Ninth Circuit's use of the two factors it determined to be crucial to its conclusion has been criticized. ${ }^{162}$ The underlying investment of capital factor has been criticized because it does not apply to all situations. ${ }^{163}$ In an in-depth note on Maginnis and the substitute-for-ordinary income doctrine, Thomas G. Sinclair notes that inherited and gifted property involve no underlying investment. ${ }^{164}$ Therefore, requiring an underlying investment of capital for capital asset status would theoretically subject all inherited and gifted property to ordinary income treatment. 165

156. Id. at $1185-86$.

157. Id. at 1186 (quoting CHIRELSTEIN, supra note 95, at 382).

158. $I d$.

159. Id. See Holt v. Comm'r, 303 F.2d 687, 691 (9th Cir. 1962) (holding that the sale of an entire interest in royalty rights was a substitute for ordinary income); Hallcraft Homes, Inc. v. Comm'r, 336 F.2d 701, 703 (9th Cir. 1964) (holding the sale of entire right to receive payments from local water companies was a substitute-for-ordinary income).

160. Maginnis, 356 F.3d at 1187. The Internal Revenue Code section 1275(a)(1)(A) defines a debt instrument as a "[b]ond, debenture, note, or certificate or other evidence of indebtedness." 26 U.S.C. $\S 1275(\mathrm{a})(1)(\mathrm{A})$.

161. Maginnis, 356 F.3d at 1187.

162. See generally Thomas G. Sinclair, Note, Limiting the Substitute-for-Ordinary Income Doctrine: An Analysis Through Its Most Recent Application Involving the Sale of Future Lottery Rights, 56 S.C. L. REV. 387 (2004) (criticizing the substitute-for-ordinary-income doctrine); Matthew S. Levine, Case Comment, Lottery Winnings as Capital Gains, United States v. Maginnis, 356 F.3d 1179 (9th Cir. 2004), 114 YALE L.J. 195 (2004) (pointing out the economic and doctrinal difficulties with the two factors of Maginnis).

163. Sinclair, supra note 162, at 421.

164. Id.

165. Levine, supra note 162, at 198. Levine suggests that perhaps Judge Fisher in Maginnis meant only that someone must have invested in the underlying asset. Id. Once someone invests 
There is also existing authority that requires ordinary income treatment in situations where the taxpayer has made an underlying investment in capital.166 The taxpayer's working interest in Lake, for example, was classified as ordinary despite the fact that the taxpayer made an initial investment in its working interests. 167 Matthew S. Levine used the example of the sale of the right to future dividends to illustrate the theoretical problem with using investment in capital to determine capital asset status. 168 Such a sale properly produces ordinary income despite there being an underlying investment.169 As stated by Levine, "the test does not account for the doctrine." 170

The Ninth Circuit's second factor - an accretion in value over the cost of the asset-has also been criticized. ${ }^{171}$ Sinclair noted that not all capital assets appreciate. ${ }^{172}$ Some capital assets, automobiles for example, typically decline in value. ${ }^{173}$ Despite the lack of appreciation these assets are clearly capital.174 Levine criticizes the use of accretion in value to determine capital asset status for "attempt[ing] to determine the character of a gain from its amount." 175

In defense of the Ninth Circuit's decision in Maginnis, it should be noted that the court did not hold that these two factors "will be dispositive in all cases." 176 The Ninth Circuit stated that these two factors were critical to their decision, but they did not adopt a two-prong test for use in all substitute-for-ordinary income cases. In addition, accretion in value has consistently been viewed as an important factor in determining whether capital asset treatment is appropriate. As previously discussed, the Supreme Court has frequently stated that Congress intended to limit capital gains treatment to situations involving the realization of appreciation in

in the asset it becomes capital and may then be donated or devised without a change in character. Id. Even with this reading of Maginnis, Levine notes other problems in applying the two-prong test of Maginnis. Id. at 197-200.

166. See, e.g., Comm'r v. P.G. Lake, Inc., 356 U.S. 260, 268 (1958) (requiring ordinary income treatment where the taxpayer converted future income into present income).

167. Lattera v. Comm'r, 437 F.3d 399, 403 (3d Cir. 2006).

168. Levine, supra note 162, at 198.

169. Id.

170. Id. The distinction between capital gain and ordinary income is now less significant in some situations because of the preferential tax rate on qualified dividends. See 26 U.S.C. $\S 1(\mathrm{~h})(11)$.

171. See generally Sinclair, supra note 162, at 421; Levine, supra note 162, at 199.

172. Sinclair, supra note 162 , at 421.

173. Id.

174. Id.

175. Lattera v. Comm'r, 437 F.3d 399, 405 (3d Cir. 2006) (citing Levine, supra note 162, at 199).

176. Levine, supra note 162 , at 197. 
value that has occurred over a substantial period of time.177 Nevertheless, the appreciation in value factor should not be decisive. It is merely one factor to consider in determining capital asset qualification. The real problem with the substitute-for-ordinary income doctrine is that it is overly broad and lacks objective standards that would assist courts in applying it on a more consistent basis.

Levine suggests an alternative approach to applying the substitute-forordinary income doctrine to the sale of lottery proceeds. 178 He advocates an approach that reaches the proper result without unnecessarily expanding the scope of the doctrine. ${ }^{179}$ Levine suggests analyzing the underlying transaction to determine the character of gain. 180 The underlying transaction in the case of the sale of future lottery payments is the receipt of gambling winnings. 181 The taxpayer avoided immediate taxation upon winning the lottery via administrative grace. $182 \mathrm{Had}$ he received the entire proceeds immediately, or been given a state of Oregon bond rather than a lottery right, it is clear that the full value of the winning would be income upon receipt. 183 Because he avoided immediate taxation on the winnings, it is "sensible to hold him responsible for the taxation that he avoided" when he sells the rights. 184

Levine goes on to suggest that an even better way to view the substitute-for-ordinary income doctrine is that there is no doctrine at all. 185 Instead, substitute-for-ordinary income can be seen as a term applied to unrelated transactions that can be better explained in other ways. 186 According to Levine, rather than classifying the assignment of the right to payment for personal services as a substitute-for-ordinary income, it makes more sense to simply note that the right is not fully taxable upon receipt, but that whenever it is received it is taxed, as it would have been upon

177. See generally Comm'r v. Gillette Motors Transp., Inc., 364 U.S. 130 (1960) (finding fair rental value payments as ordinary income).

178. Levine, supra note 162, at 199.

179. Id.

180. $I d$.

181. Id. at 200 .

182. Id. Levine notes that the rationale for not taxing the entire value of the lottery winnings immediately may be related to the realization principle of Eisner v. Macomber, 252 U.S. 189 (1920). Id. The realization requirement is based on principles of liquidity and valuation. Id. Assets that are not realized upon receipt because of valuation and liquidity concerns, "are substitutes for ordinary income in the hands of those who receive them in ordinary-income transactions (e.g., as gambling winnings)." Id.

183. $I d$.

184. Id.

185. $I d$.

186. $I d$. 
receipt. 187 A type of open transaction analysis applies. 188 When the transaction is closed (by the sale of the right to future payment), taxation is based on the character of the original transaction, resulting in ordinary income treatment. 189

\section{THE THIRD CIRCUIT'S DECISION IN LATTERA}

\section{A. FACTS}

The taxpayers in Lattera won $\$ 9,595,326$ in the Pennsylvania lottery. 190 They were entitled to twenty-six annual installments of $\$ 369,051.191$ They did not have the option to receive the prize in a lump sum payment.192 In 1999, after receiving seven annual installments, the taxpayers sold their rights to the seventeen remaining payments to a finance company for $\$ 3,372,342.193$ The taxpayers reporting the transaction as the sale of a long-term capital asset, with a sales price of $\$ 3,372,342$ and a basis of zero. 194 The IRS determined that the sales price was ordinary income and in 2002 sent the taxpayers a notice of deficiency for $\$ 660,784.195$

The Tax Court held that the sale of the future lottery payments resulted in ordinary income.196 The taxpayers argued that Davis was wrongly decided.197 The Tax Court stated that it has "repeatedly relied upon the analysis in Davis," and reaffirmed its decision without detailed analysis. 198 The argument that the taxpayers sold the lottery ticket, not the right to future lottery payments, was again rejected by the Tax Court. 199

187. Id. at 201.

188. $I d$.

189. $I d$.

190. Lattera v. Comm'r, 437 F.3d 399, 401 (3d Cir. 2006).

191. $I d$.

192. Id.

193. Id. Pennsylvania law required the Latteras to obtain court approval before transferring their rights to future lottery payments. Id. They did so in August 1999. Id.

194. Id.

195. Id.

196. Lattera v. Comm'r, 88 T.C.M. (CCH) 293 (2004).

197. Id. at 294.

198. Id. The Tax Court summarily stated that "[n]o purpose would be served by repeating the analysis in Davis regarding why the right to receive future annual lottery payments does not constitute a capital asset." Id.

199. Id.; see also Simpson v. Comm'r, 85 T.C.M. (CCH) 1421 (2003) (rejecting claim that winning lottery ticket was a capital asset); Johns v. Comm'r, 85 T.C.M. (CCH) 1318 (2003) (dismissing argument winning lottery ticket is property and a capital asset). 


\section{B. AdOPTING A FAMILY RESEMBLANCE TEST}

The Third Circuit court stated that the question of whether the sale of the right to receive future lottery payments can be treated as the sale of a capital asset was a question of first impression in the Third Circuit, but not a new question. 200 However, the Third Circuit noted the criticism 201 of the Ninth Circuit's reasoning in Maginnis and proposed a different approach to the question. 202 The Third Circuit adopted a "family resemblance" test to determine the character of gain on the sale of lottery proceeds. 203

The taxpayer in Lattera argued that the substitute-for-ordinary income doctrine did not survive Arkansas Best.204 The Third Circuit agreed with the Tax Court's previous conclusion that Arkansas Best did not in any way affect the substitute-for-ordinary income doctrine and held that it remains viable. 205

The Third Circuit noted the tension inherent in the substitute-forordinary income doctrine. ${ }^{206}$ Theoretically, "all capital assets are substitutes for ordinary income." 207 Such a narrow reading of the substitutefor-ordinary income doctrine would "completely swallow the concept of capital gains." 208 At the other extreme, an overly broad reading of the doctrine "would create potential for the abuse of treating capital losses as ordinary."209 The Third Circuit sought to develop a guide for applying the substitute-for-ordinary income doctrine so as not to err on either side of these two extremes.210 They acknowledged that determining whether a particular transaction results in ordinary income or capital gain under the substitute-for-ordinary income doctrine involves a case-by-case analysis and that any rule developed could not account for every possible transaction.211 In crafting its analysis, the Third Circuit relied on both a family resemblance test adopted by the Second Circuit for use in determining

200. Lattera v. Comm'r, 437 F.3d 399, 401 (3d Cir. 2006). The Third Circuit cited the Ninth's Circuit's decision in Maginnis, as well as the Tax Court's previous decisions on the issue. Id. at 402 .

201. See generally Sinclair, supra note 162, at 421 (criticizing the two-prong test of Maginnis); Levine, supra note 162, at 197-200 (noting the difficulties with the Maginnis twoprong test).

202. Lattera, 437 F.3d at 402.

203. Id. at 406 .

204. Id. at 403 .

205. Id. at 404 .

206. Id.

207. Id.

208. Id. (quoting Levine, supra note 162, at 196).

209. Id. (quoting Levine, supra note 162, at 197).

210. Id.

211. Id. at 405 . 
whether a note is a security, and Sinclair's comment.212 The Third Circuit then adopted an "analogous analysis." 213

The family resemblance test was first used by the Second Circuit in Exchange National Bank of Chicago v. Touch Ross \& Co.,214 to determine whether a note was a security for purposes of section 10(b) of the 1934 Securities and Exchange Act.215 The Second Circuit created the family resemblance test by presuming that notes of more than nine months maturity were securities, listing various types of notes that it did not consider securities, and declaring that a note with a maturity value exceeding nine months "does not bear a strong family resemblance" to the notes it did not consider securities was a security.216 The Supreme Court adopted the family resemblance test for securities in Reves v. Ernst \& Young. 217 Reves added four factors to assess whether a particular transaction bears a family resemblance to a security: the motivations that would prompt a reasonable buyer and seller to enter into a transaction, the " "plan of distribution" of the instrument to determine whether there is "common trading for speculation or investment," the public's reasonable expectations, and the existence of another regulatory scheme that significantly reduces the risk of investment. 218

\section{APPlying the Family Resemblance Test to the Substitute- FOR-ORDINARY INCOME DOCTRINE}

\section{Opposite Ends of the Capital versus Ordinary Spectrum}

In applying the family resemblance test to determine capital asset qualification, the Third Circuit noted the two opposite ends of the spectrum.219 At one end of the spectrum are assets that are clearly capital.220 The court cited "stocks, bonds, options, currency contracts" and "physical assets like land and automobiles" as assets that are clearly capital.221

212. Id. (citing Sinclair, supra note 162 , at 406 ).

213. Id. at 405 .

214. 544 F.2d 1126 (2d Cir. 1976).

215. Exch. Nat'l Bank of Chi., 544 F.2d at 1138.

216. $I d$.

217. 494 U.S. 56 (1990).

218. Reves, 494 U.S. at 66-67. Although most commentators approved of Reeves, others have criticized the decision on various grounds. See, e.g., John C. Cody, The Dysfunctional "Family Resemblance" Test: After Reves v. Ernst \& Young, When are Mortgage Notes "Securities"?, 42 BUFF. L. REV. 761, 797-99 (1994). A review of the family resemblance doctrine as it applies to securities is beyond the scope of this article.

219. Lattera v. Comm'r, 437 F.3d 399, 405-06 (3d Cir. 2006).

220. Id. at 406 .

221. Id. 
At the other end of the spectrum are assets, such as rental and interest income, that are clearly ordinary.222 The Third Circuit cited Gillette Motor in support of rental income being clearly ordinary, and Midland-Ross in support of interest being clearly ordinary. 223

For those transactions that do not bear a strong family resemblance to either end of the spectrum, the Third Circuit adopted two factors to assist in determining whether a particular transaction should be treated as capital or ordinary: “(1) type of 'carve-out' and (2) character of [the] asset."224

\section{Type of "Carve-Out"}

"There are two [distinct] ways of carving out interests from property: horizontally and vertically."225 A horizontal carve-out exists when the person owning an interest in property disposes of part of his interest but also keeps part of it.226 The Third Circuit noted that this is what happened in Hort (a term of years carved out from a fee simple) and Lake (a threeyear payment right from a working interest in an oil lease). ${ }^{227}$ According to the Third Circuit, a horizontal carve-out leads to ordinary income treatment. 228

A vertical carve-out involves "a complete disposition of a person's interest in property." 229 Although a vertical carve-out is different than a horizontal carve-out (which automatically receives ordinary income treatment), it is not necessarily treated as capital.230 The Third Circuit cited the Ninth Circuit's discussion in Maginnis to demonstrate that vertical carveouts are not automatically entitled to capital gain treatment.231 Under the Third Circuit's family resemblance test, the second factor-the character of

222. $I d$.

223. $I d$.

224. Id. Although the test adopted by the Third Circuit in Lattera is not identical to that suggested by Sinclair, the two factors adopted to determine the character of gain in transactions that do not bear a strong family resemblance to either end of the capital versus ordinary spectrum are borrowed from Sinclair. Id. at 406 n.4. However, the Third Circuit differs slightly from Sinclair in the way they apply the character factor. $I d$.

225. Id.

226. $I d$.

227. $I d$.

228. $I d$.

229. $I d$.

230. $I d$.

231. Id. at 407. The relevant part of Maginnis cited by Lattera held "that a transaction in which a taxpayer sells his entire interest in an underlying asset without retaining any property right does not automatically prevent application of the substitute for ordinary income doctrine (emphasis in original)." Id. The Third Circuit also cited the Tax Court's decision in Watkins as a case where the lottery winner assigned the entire right to all remaining lottery payments. Id. 
the asset-is analyzed to determine whether a vertical carve-out is ordinary or capital.232

\section{Character of the Asset}

According to the Third Circuit, assets that constitute a right to earn income merit capital gain treatment, while assets that constitute a right to earned income merit ordinary income treatment.233 The Third Circuit reviewed Sinclair's explanation of this concept in support of their conclusion.234 Earned income entitles the owner of the property to the income merely by owning the property.235 Examples include rental income, stock dividends, and rights to future lottery payments. 236

In the case of the right to earn income, on the other hand, mere ownership of the asset does not entitle the owner to income.237 The owner of the asset must do something further to earn the income.238 The Third Circuit cited United States v. Dresser Industries, Inc. 239 to illustrate the difference between the right to earn income and the right to earned income. ${ }^{240}$ The taxpayer in Dresser Industries had assigned its right to an exclusive patent license to the patent holder in exchange for a share of licensing fees.241 The Fifth Circuit held that the taxpayer was entitled to capital gain treatment because the asset sold was not a right to earned income to be paid in the future, but was, instead, an asset that would produce income. 242

The Third Circuit cited their earlier decision in Tunnell v. United States $^{243}$ as further support for this position.244 The taxpayer in Tunnell withdrew from a law partnership, and assigned his rights in the law firm in exchange for $\$ 27,500.245$ At the time of his withdrawal, the partnership also had over $\$ 21,000$ in uncollected receivables for work that had already been done.246 The sale of the partnership interest was held to be capital.247

232. Id.

233. Id. at 408 .

234. Id.

235. Id.

236. Id.

237. Id

238. Id.

239. 324 F.2d 56 (5th Cir. 1963).

240. Lattera, 437 F.3d at 407 (citing Dresser Industries, Inc., 324 F.2d at 59).

241. Id. at 408 .

242. $I d$.

243. 259 F.2d 916 (3d Cir. 1958).

244. Lattera, 437 F.3d at 408 (citing Tunnell, 259 F.2d at 917).

245. Id.

246. Id. 
The sale in and of itself did not confer income on the buyer.248 The buyer had to continue to provide services to earn income. 249 The accounts receivable, on the other hand, had already been earned.250 Its sale was the sale of the right to earned income and therefore ordinary.251 The Third Circuit cited a termination fee for a personal services contract as another example of the sale of earned income.252 The employee no longer has to perform services in exchange for the fee and therefore it is a right to earned income. 253

The Third Circuit stated that the character of the asset factor also explains the Second Circuit's decision in Commissioner of Internal Revenue v. Ferrer. 254 In Ferrer, the actor Jose Ferrer had contracted for the rights to mount a stage production of the novel Moulin Rouge.255 The contract gave him the exclusive right to produce and present a play based on the novel, the right to veto any disposition of movie rights prior to the time the play had run for a specified period of time, and the right to a percentage of the proceeds from any motion-picture rights if the play was produced and the movie rights were sold.256 Ferrer sold these rights after a movie studio planned to make Moulin Rouge into a movie and agreed that it would feature him.257 In a detailed analysis, the Second Circuit held that the right to produce and present the play was capital, and the right to share in the proceeds was ordinary.258 In the language of the Third Circuit's family resemblance test, the right to produce and present the play was a

247. Id.

248. Id.

249. Id.

250. Id.

251. Id.

252. Id.

253. Id. As stated by the Third Circuit, "the employee still possesses the asset (the right to provide personal services) and the money (the termination fee) has already been 'earned' and will be paid." Id.

254. 304 F.2d 125 (2d Cir. 1962).

255. Lattera, 437 F.3d at 409.

256. $I d$.

257. Id.

258. Id. The Second Circuit viewed the right to produce the play as analogous to a lease of the story property. Ferrer, 304 F.2d at 132. The right to share in the proceeds of the play, on the other hand, was merely a claim to further income from lease of the play. $I d$. It was comparable to a lessee's right to receive a percentage of what the lessor obtained from other tenants attracted to the building by the lessees operations. Id. at 134. Because such a percentage payment would be ordinary income when received, a lump-sum payment for the sale of the rights should be ordinary as well. Id. 
right to earn income.259 Once the play was produced, the right to share in the proceeds was the right to earned income. 260

\section{APPLying THE FAMILY RESEMBlance TEST to the FACTS}

Applying the newly adopted family resemblance test to the facts at hand, the Third Circuit stated that the right to receive future lottery payments does not bear a strong family resemblance to either the capital asset or ordinary income end of the spectrum.261 The Third Circuit then looked to the type of carve-out involved.262 The sale of future lottery proceeds in Lattera involved a vertical carve-out, which could result in either capital gain or ordinary income treatment.263 Therefore, the court examined the character of the asset sold.264 Because the right to lottery payments is a right to earned income (the taxpayers were entitled to the payments simply by owning the asset), the proceeds of the sale were classified as ordinary income. 265

\section{ANALYSIS OF THE FAMILY RESEMBLANCE TEST AS APPLIED TO THE SUBSTITUTE-FOR-ORDINARY INCOME DOCTRINE}

All courts that have addressed the character of the sale of future lottery payments have used the substitute-for-ordinary income doctrine to characterize the sale proceeds as ordinary. Given the prior decisions on the issue, the result in Lattera is not surprising or significant. The Third Circuit's opinion in Lattera, however, is significant for its adoption of the family resemblance test to differentiate between ordinary income and capital gain. Commentators have suggested that Lattera is "an opinion destined for law school casebooks." 266 The Third Circuit's family resemblance test can be used in all substitute-for-ordinary income doctrine cases, not just those involving the sale of future lottery payments.

The character of the assets the Third Circuit lists as representing the extreme ends of the capital versus ordinary spectrum are all well supported

259. Lattera, 437 F.3d at 409.

260. Id.

261. Id.

262. Id

263. Id. Lattera involved a vertical carve out because the taxpayers assigned their entire interest in the future lottery payments. $I d$.

264. Id. at 410 .

265. Id. The Third Circuit noted that their result comports with the results reached by the Tax Court in Davis and the Ninth Circuit in Maginnis. Id.

266. Simmons, supra note 3, at 953. 
by case law. The assets listed as clearly capital deserve capital gain treatment. These assets have the potential for the realization of appreciation accrued over a substantial period of time in a single year.267 Assets listed by the Third Circuit as clearly ordinary are taken directly from Gillette Motor and Midland-Ross.

The real significance of the family resemblance test is the factors adopted by the Third Circuit to determine the character of gain in transactions that lie between the opposite ends of the capital versus ordinary spectrum. These factors are not new. Commentators have long argued that the type of carve-out is the key to the ordinary versus capital classification.268 A horizontal carve-out should always result in ordinary income treatment. Taxpayers should not be able to convert ordinary income into capital gain by disposing of a partial interest in property.269 Some commentators have stated that the character of the gain turns on whether the taxpayer retains an interest in the property transferred.270 The lottery cases clearly indicate this factor alone is not sufficient. As correctly stated in both Maginnis and Lattera just because a carve-out is vertical does not mean it is automatically entitled to capital gain treatment. 271

The right to earn income versus the right to earned income factor provides a clear guide for determining whether vertical carve-outs merit capital gain treatment. The right to earn income necessarily means the recipient must take affirmative steps to earn the income. Ordinary income treatment is proper in such situations. On the other hand, no further action is necessary in the case of the right to earned income. The transaction is closed and more closely resembles the typical sale of a capital asset.

267. See supra notes 171-77 and accompanying text for a discussion of the criticism of using accretion in value as a factor in applying the substitute for ordinary income doctrine.

268. See generally Shores, supra note 95 (analyzing property versus income distinction); CHIRELSTEIN, supra note 95, at 383-84 (discussing substituting language to carve out interests).

269. Borrowing from the "fruit-and-tree" analogy that applies to the assignment of income doctrine, taxpayers should not be able to obtain capital gain treatment while maintaining an ownership interest in the underlying property. See generally Lucas v. Earl, 281 U.S. 111 (1930) (holding husband taxed on earnings from personal services assigned to his wife); Helvering v. Horst, 311 U.S. 112 (1940) (holding income from detachable interest coupons taxed to the owner of the bonds).

270. See Louis A. Del Cotto, "Property" in the Capital Asset Definition: Influence of "Fruit and Tree," 15 BUFF. L. REV. 1 (1965-66) (discussing the effect of the "fruit-and-tree" analogy on property as a capital asset).

271. See United States v. Maginnis, 356 F.3d 1179, 1185 (9th Cir. 2004) (selling underlying asset without retention of property right does not automatically preclude application of doctrine); Lattera v. Comm'r, 437 F.3d 399, 407 (3d Cir. 2004) (explaining that vertically carving-out does not necessarily mean capital gain). 


\section{CONCLUSION}

In conclusion, although the factors adopted by the Third Circuit in Lattera are not new, incorporating them into the family resemblance test is significant because it gives courts a framework within which to apply the substitute-for-ordinary income doctrine. The test may prove to be imperfect and new factors may need to be developed to deal with particular factual situations, but it is a step in the right direction. Applying the family resemblance test to the substitute-for-ordinary income doctrine is an improvement over the overly broad language that has plagued the doctrine for years. If adopted by other courts, it will add much needed certainty to the substitute-for-ordinary income doctrine. 